\title{
$\mathbb{K}_{\text {ajian }}$ Analitik
}

\section{MASALAH-MASALAH PENYULUHAN PERTANIAN}

\author{
I Gd. Setiawan AP.
}

Ibarat orang buta yang sedang menduga-duga seekor binatang yang bernama Gajah, maka suatu objek amatan dapat diinterpretasikan bermacam-macam sesuai sudut pandang dan kemampuan orang tersebut. Apabila yang dipegang oleh orang buta tersebut adalah belalai si Gajah, maka ia menyimpulkan bahwa Gajah adalah binatang yang bulat panjang, dan tidak bisa diam. Apabila yang dipegang kebetulan adalah salah satu kakinya, maka ia dapat menyimpulkan bahwa gajah adalah binatang yang kokoh bagaikan tiang listrik yang biasa mereka pegang dipinggir jalan. Demikian seterusnya. Sama dengan analogi orang buta memegang gajah, maka masalah-masalah penyuluhan pertanian yang dihadapi bangsa kita akan beragam sesuai dengan sudut pandang dan dasar keilmuan yang ditekuni. Menemukan masalah-masalah penyuluhan bukan sarana untuk mendebat bahkan menyalahkan orang lain, tetapi mencari solusi demi perbaikan kegiatan penyuluhan di Indonesia. Berikut akan diuraikan masalah-masalah penyuluhan yang telah terjadi dan sedang terjadi ditinjau dari kacamata Ilmu Penyuluhan Pembangunan

\section{Penyuluh Melupakan Tugas Utama}

Tugas utama penyuluhan adalah membantu petani di dalam pengambilan keputusan dari berbagai alternatif pemecahan masalah. Tetapi masalah penyuluhan sekarang adalah kegiatan penyuluhan lebih banyak pada proses pelayanan bukan mendidik petani agar mampu mengambil keputusan sendiri.

\section{Keadaan Petani yang Menghambat Kegiatan Penyuluhan}

Hambatan-hambatan menghalangi pencapaian tujuan dapat ditanggulangi sesuai dengan sifatnya. Hambatan-hambatan tersebut dapat dikelompokkan sebagai berikut:

\section{Pengetahuan}

Sebagian petani tidak mempunyai pengetahuan serta wawasan yang memadai untuk dapat memahami permasalahan mereka, memikirkan pemecahannya, atau memilih pemecahan masalah yang paling tepat untuk mencapai tujuan mereka. Tugas agen penyuluh adalah meniadakan hambatan tersebut dengan cara menyediakan informasi dan memberikan pandangan mengenai masalah yang dihadapi. Agen penyuluh dapat memberikan bantuan berupa pemberian informasi yang memadai yang bersifat teknis mengenai masalah yang dibutuhkan petani dan menunjukkan cara penanggulanganya. Selama penyuluh belum mampu memberikan informasi yang dibutuhkan petani tersebut, maka kegiatan penyuluhan tidak akan berjalan dengan baik.

\section{$\underline{\text { Motivasi }}$}

Motivasi berasal dari kata motive dan action, artinya bagaimana membuat orang untuk berusaha. Sebagian besar petani kurang memiliki motivasi untuk mengubah perilaku karena perubahan yang diharapkan berbenturan dengan motivasi yang lain. Kadang-kadang penyuluhan dapat mengatasi hal demikian dengan membantu petani mempertimbangkan kembali motivasi mereka. Petani kurang dimotivasi berusaha untuk 
merubah cara-cara tradisional kearah modernisasi. Atau sifat pertanian yang subsisten kurang diarahkan untuk berorientasi pada pasar. Selama petani belum dimotivasi, maka akan menjadi masalah.

Sumber daya

Beberapa organisasi penyuluhan bertanggung jawab untuk meniadakan hambatan yang disebabkan oleh kekurangan sumber daya. Kegiatan penyuluhan di Indonesia biasanya berada di bawah Departemen Pertanian seringkali diberikan tanggung jawab untuk mengawasi kredit dan mendistribusikan sarana produksi seperti pupuk. Masalahnya sekarang adalah organisasi yang menyediakan sumber daya tersebut tidak terlibat melainkan dilakukan oleh penyuluh. Seharunsya kegiatan pelayanan dilakukan oleh lembaga service, kegiatan pengaturan dilakukan oleh lembaga regulation dan kegiatan penyuluhan hanya dilakukan oleh lembaga penyuluhan. Apabila ketiga lembaga ini dapat berfungsi dengan baik maka kegiatan pembangunan pertanian juga akan berjalan dengan baik.

\section{Wawasan}

Sebagian petani kurang memiliki wawasan untuk memperoleh sumber daya yang diperlukan. Masalah ini hampir sama dengan hambatan pengetahuan, dan peranan penyuluhan sangat diperlukan pada keadaan seperti ini. Tugas penyuluh adalah memberikan pandangan supaya wawasan petani menjadi lebih luas.

\section{$\underline{\text { Kekuasaan }}$}

Penyediaan informasi tidaklah mungkin membawa perubahan dalam hal kekuasaan petani. Dengan demikian, hal ini tidak dapat dilaksanakan sebagai kegiatan penyuluhan kecuali penyebabnya adalah hambatan wawasan terhadap kekuasaan.

Wawasan terhadap kekuasaan

Sebagian petani tidak memiliki
wawasan terhadap kekuasaan, terhadap
hubungan-hubungan kekuasaan dalam
masyarakatnya maupun tentang sumber daya
kekuasaan yang tersedia bagi mereka serta

cara menggunakannya untuk menciptakan perubahan.

Petani Adalah Orang yang Terpinggirkan (Marginal)

Kekuasaan petani untuk mengeluarkan pendapat belum diperhatikan. Petani adalah orang yang memiliki status sosial yang rendah, perekonomian yang lemah dan penguasaan tanah yang sangat sempit. Petani lemah inilah yang harus diberdayakan untuk membentuk suatu asosiasi petani. Contoh: Asosiasi petani tebu jawa tengah, Asosiasi petani tebu Jawa timur, dan lain-lain sehingga petani tebu tersebut menjadi kuat. Selain petani penyuluh juga harus membentuk asosiasi penyuluh sehingga kuat untuk mempejuangkan nasib petani. Tanpa berkelompok petani dan penyuluh tidak ada artinya.

\section{Bagaimana Penyuluh Membantu Petani?}

Penyuluh berada pada dua kepentingan yaitu kepentingan petani dan kepentingan pemerintah. Kepentingan pemerintah adalah untuk mencukupi kebutuhan pangan oleh karena itu petani diharapkan meningkatkan produksi tetapi dengan harga yang murah. Kepentingan petani adalah untuk meningkatkan kesejahteraan keluarganya dan mengusahakan kegiatan pertanian yang berkelanjutan. Penyuluh berada pada dua kepentingan yang saling bertentangan. Selama penyuluh berpihak kepada pemerintah, maka akan timbul konflik kepentingan petani dan pemerintah. Kepercayaan petani kepada penyuluh akan menurun. Partisipasi petani dalam pembangunan juga akan menurun. Contoh: Petani menginginkan harga buah meningkat karena memiliki warna yang bagus, tetapi pemerintah tidak dapat memenuhinya.

\section{Kegiatan Penyuluhan Kurang Terorganisasi}

Kurang terorganisasinya penyuluhan secara baik. Contoh: pada jaman BIMAS dikeluarkan SK Mendagri-Mentan tahun 1985 tentang pembentukan BPP (Balai Penyuluhan Pertanian) sehingga penyuluh pertanian 
berada di BPP. Kemudian tahun 1992 penyuluh berda di dinas-dinas sehingga BPP di bagi-bagi sesuai dengan dinas yang ada. Tahun 1996 dikeluarkan SK MendagriMentan tentang pembentukan BIPP (Balai Informasi Penyuluhan Pertanian). Belum selesai BIPP dibentuk sudah digulirkannya UU No. 22 tahun 1999 tentang Otonomi Daerah. Kurangnya pengorganisasian kegiatan penyuluhan menyebabkan kurangnya keberhasilan penyuluhan pertanian.

\section{Kegiatan Penyuluhan Tidak Berjalan dengan Baik}

Kegiatan penyuluhan akan berjalan dengan baik bila: pasar, teknologi, input, intensitas produksi (harga yang layak) dan transportasi desa mencapai keadaan maksimum. Bagaimana membangun pertanian yang baik bila $80 \%$ masalah berada di luar petani. Kegiatan penyuluhan tidak efektif apabila kelima masalah diatas tidak diatasi.

\section{Kelembagaan Penyuluhan belum Tertata dengan Baik}

Selama ini kegiatan penyuluhan lebih dilaksanakan oleh lembaga penerangan yang bertanggung jawab untuk menjembatani kebijakan pemerintah agar sampai kepada rakyat. Seharusnya penyuluhan lebih mendidik petani agar dapat memecahkan masalahnya sendiri. Organisasi penyuluhan yang sekarang ini ingin menyampaikan kebijakan yang sebenarnya dilakukan oleh lembaga penerangan.

\section{Penyimpangan Tujuan Organisasi Penyuluhan}

Organisasi penyuluhan bertujuan untuk memecahkan masalah yang dihadapi petani. Penyuluh harus memainkan peranan bagaimana petani terlibat dalam kegiatan penyuluhan. Tujuan kegiatan yang terjadi sekarang ini sangat jauh dari harapan. Tujuan tersebut dapat dilihat pada Tabel 1.
Tabel 1. Sikap-sikap yang berbeda dari berbagai organisasi penyuluhan

\begin{tabular}{|c|c|}
\hline Kenyataan & Harapan \\
\hline $\begin{array}{ll}\text { - } & \text { Bertujuan } \\
\text { meningkatkan } \\
\text { - } & \text { produktivitas } \\
\text { - } & \text { Semata-mata } \\
\text { - } & \text { Agenyuluhan } \\
\text { - } & \text { Terpusat } \\
\text { - } & \text { Bekerja dalam } \\
& \text { skala nasional } \\
\text { - } & \text { Semata-mata alih } \\
\text { - } & \text { pengetahuan } \\
\text { Diarahkan }\end{array}$ & $\begin{array}{ll}\text { - } & \text { Bertujuan } \\
& \text { memecahkan } \\
\text { masalah } \\
\text { - } & \text { Holistik } \\
\text { - } & \text { Pelayanan terpadu } \\
\text { - } & \text { Bantuan sendiri } \\
& \text { berdasarkan } \\
& \text { organisasi swasta } \\
\text { - } & \text { Tidak terpusat, } \\
\text { - } & \text { Bartisipatif } \\
\text { Bekerja dalam } \\
\text { wilayah kecil } \\
\text { Juga menghasilkan } \\
\text { pengetahuan } \\
\text { Tidak diarahkan }\end{array}$ \\
\hline
\end{tabular}

\section{Perbedaan Nilai yang Dianut Petani dan Agen Penyuluh}

Nilai-nilai yang dianut petani kemungkinan berbeda dari nilai-nilai agen penyuluhan yang "berbau perkotaan", tetapi tidak beralasan jika beranggapan bahwa nilainilai agen penyuluhan dan atasannya lebih baik dibandingkan nilai-nilai petani dan keluarganya. Selama penyuluh belum bisa menyamakan nilai-nilai yang dianut ini maka akan timbul masalah.

\section{Pengetahuan Penyuluh Kurang Memadai}

Agen penyuluh hanya memiliki setengah dari pengetahuan yang diperlukan untuk mengambil keputusan, sedangkan petani dan keluarganya melengkapi kekurangannya. Mereka akan mengetahui tujuan-tujuan mereka, jumlah modal yang dimiliki, persyaratan tenaga kerja pertanian mereka selama bulan-bulan yang berbeda, hubungan dengan petani lain, kualitas lahan serta kesempatan-kesempatan menghasilkan uang diluar sektor pertanian. Agen penyuluhan mungkin memiliki sebagian dari pengetahuan tersebut, tetapi biasanya tidak sebanyak pengetahuan yang dimiliki oleh keluarga petani sendiri. 
Dewasa ini agen penyuluhan lebih mengarahkan langkahnya pada sistem pertanian yang berkelanjutan dan kurang memperhatikan input pertanian yang tinggi dibandingkan tahun-tahun yang lalu. Pengetahuan khas setempat dari petani sangatlah penting untuk mengembangkan pertanian yang berkelanjutan karena cara ini harus disesuaikan dengan situasi setempat yang biasanya petani tahu lebih banyak dibandingkan peneliti atau agen penyuluhan.

\section{Mengubah Cara Bertani atau Mengubah Petani}

Kebanyakan agen penyuluhan petanian memperoleh pendidikan formal tentang cara-cara mengubah atau memperbaiki cara bertani. Mereka belajar tentang varietas tanaman, pupuk, makanan ternak, dan sebagainya, tetapi di dalam tugasnya diminta untuk "mengubah petani" yang kemudian dapat membuat keputusan untuk mengubah "usaha taninya". Banyak agen penyuluh belum terlatih dalam proses mengubah sikap, yaitu dalam hal pendidikan orang dewasa dan komunikasi. Mereka diajar mengenai "apa yang harus dilakukan" kepada petani, tetapi tidak tentang "bagaimana" mengatakannya agar petani mampu menjadi manajer yang baik dalam usaha taninya. Perubahan yang demikian merupakan salah satu tujuan penting dari pendidikan penyuluhan.

\section{Penyuluh Kurang Membantu Petani Mencapai Tujuan}

Selama ini kegiatan penyuluhan kurang membantu petani mencapai tujuan. Agen penyuluhan dapat memanfaatkan berbagai cara untuk membantu kliennya untuk mencapai tujuannya, yaitu:

- Memberi nasihat secara tepat waktu guna menyadarkannya tentang suatu masalah,

- menambahkan kisaran alternatif yang dapat menjadi pilihannya,

- memberi informasi mengenai konsekuensi yang dapat diharapkan dari masingmasing alternatif,
- membantunya dalam memutusakan tujuan mana yang paling penting,

- membantunya dalam mengambil keputusan secara sistematis baik secara perorangan maupun berkelompok,

- membantunnya belajar dari pengalaman dan dari pengujicobaan,

- mendorongnya untuk tukar-menukar informasi dengan rekan petani.

\section{Penyuluh Kurang Membuat Wadah untuk Kepentingan Petani}

Di negara industri maju petani dengan berbagai cara membuat wadah untuk memenuhi kepentingan bersama mereka. Organisasi demikian memegang peranan penting dalam pembangunan pertanian di negara industri maju. Di negara berkembang belum ada organisasi demikian, atau kalaupun ada cenderung belum efektif. Adanya organisasi pertanian yang efektif sama pentingnya dengan penerapan teknologi di banyak negara. Organisasi penyuluhan memegang peranan penting dalam membimbing petani mengorganisasikan diri secara efektif. Walaupun demikian diperlukan dukungan politik untuk dapat berperan tanpa membahayakan jabatan mereka.

\section{Penyuluh Kurang Mendidik Petani}

Tugas mendidik dan pendidikan penyuluhan merupakan cabang dari pendidikan orang dewasa. Agen penyuluhan di banyak negara Eropa lebih merupakan seseorang yang menolong petani untuk memecahkan masalah mereka. Agen penyuluhan sudah merasa puas jika pertanian menjadi lebih efisien, dan kurang berminat untuk mengubah petani. Tugas utama penyuluhan di banyak negara berkembang adalah menganjurkan penggunaan teknologi modern, seperti pemakaian pupuk. Kenaikan hasil merupakan tujuan utama di negaranegara berkembang karena cepatnya pertumbuhan penduduk, disamping adanya anggapan bahwa petani terbelakang dan tradisional. 
Petani dapat dididik dengan dua cara yang berbeda: 1) mengajari mereka bagaimana cara memecahkan masalah spesifik, atau 2) mengajari mereka proses pemecahan masalah. Cara kedua memerlukan banyak waktu dan upaya dari kedua pihak, tetapi untuk jangka panjang menghemat waktu dan menambah kemungkinan dikenalinya gejala hama dan penyakit secara tepat waktu dan segera dapat ditanggulangi. Cara demikianlah yang terbaik, tetapi perlu disadari bahwa seseorang yang diberi pendidikan sepotong-sepotong lebih berbahaya dari orang buta huruf. Petani wajib diberi pengertian tentang masalah mana yang dapat mereka pecahkan sendiri dan manakah yang tidak.

Petani di negara berkembang juga ingin memperbaiki cara bertani mereka, dan kewajiban agen penyuluhan adalah mendukung dan menciptakan proses demikian melalui belajar yang disebut "belajar mandiri" atau self-directed learning

\section{Penyuluh Kurang Mengubah Keadaan Petani}

Selama bertahun-tahun konservatisme petani dianggap sebagai penyebab kegagalan adopsi teknologi yang dikembangkan penelitian. Hal demikian ternyata tidak selalu benar, karena cara bertani yang tidak menguntungkanlah yang membuat mereka tidak menggunakan teknologi tersebut.

\section{Rujukan}

Padmowihardjo, $\quad$ Soedijanto. 2001. Penyelenggaraan Penyuluhan Pertanian dalam Pembangunan Sistem dan Usaha Agribisnis. Departemen Pertanian. Jakarta.

Van Den Ban dan Hawkins. 1999. Penyuluhan Pertanian. Agnes Dwina Herdiastuti, penerjemah. Terjemahan dari Agricultural Extention (Second Edition). Kanisius. Jakarta 